\title{
TRADISI NYANYIAN ANAK TERHADAP PEMBENTUKAN KARAKTER ANAK USIA SEKOLAH DASAR
}

\author{
M. Ridwan \\ Mas'odi \\ Prodi PGSD STKIP PGRI Sumenep \\ Jl. Trunojoyo Gedungan Sumenep \\ Email: ridwan_esto@yahoo.co.id.
}

\begin{abstract}
Abtract: The objectives of this study are to (1) obtain an objective description of local wisdom in the form of children folk song; (2) identify folk song within children's game in Sumenep; and (3) examine children's game folk song as a media to develop children's character as well as the stimulus for the development of motoric, social emotional, cognitive, and language. This research is a qualitative design using ethnography. Children's traditional games in Saronggi are ti'titti' liya' liyu', ko-soko bucang, kotana mera, jang kolajang, cong-koncong konce. In addition, in West kerta Village the children games are Tan-Pangantanan and Pesapean Pappa while in Juruan Daya Village are Ker-Tanongker and Pa' Opa' Eling.
\end{abstract}

Keywords: local wisdom, traditional games, children character, elementary school

\begin{abstract}
Abstrak: Tujuan penelitian ini adalah: (1) memperoleh deskriptif objektif kearifan lokal permainan tradisional yang dinyanyikan anak-anak; (2) mengidentifikasi permianan tradisional yang dinyanyikan di Sumenep; dan (3) mengkaji permainan tradisional yang dinyanyikan sebagai media pembentukan karakter anak sekaligus sebagai stimulus perkembangan fisik motorik, sosial emosional, kognitif dan bahasa. Penelitian ini adalah penelitian kualitatif jenis etnografi. Permainan anak tradisional yang terdapat di Desa Saronggi adalah ti 'titti liya` liyu`, ko-soko bucang, kotana mera, jang kolajang, cong-koncong konce. Permainan anak tradisional lainnya seperti Tan-Pangantanan dan Pesapean Pappa terdapat di Desa Kerta Barat dan permainan Ker-Tanongker dan $\mathrm{Pa}^{\prime} \mathrm{Opa}$ 'Eling terdapat di Desa Juruan Daya.
\end{abstract}

Kata kunci: kearifan lokal, permainan tradisional, karakter anak. SD

Berlatar belakang terjadinya sengketa antara Indonesia dan Malaysia terkait penggunaan beberapa Folklor yang diklaim kepemilikannya oleh Malaysia, dalam hal ini Perlindungan Atas Pengetahuan Tradisional dan Ekspresi Budaya Tradisional Atau Folklor (PTEBT) di Indonesia mendapat perhatian lebih kuat dewasa ini. Pemerintah Indonesia sesungguhnya telah mengakui pentingnya nilai kekayaan intelektual yang ada dalam folklor Indonesia sejak pertama kali mereka mengundangkan un- dang-undang Hak Cipta nasional 1982 (lihat Pasal 10 Undang Undang No. 6/1982 tentang Hak Cipta, yang selanjutnya diakui juga dalam Pasal 10 Undang-Undang No. 19/2002 tentang Hak Cipta, dan terakhir dalam pasal RUU Hak Cipta tahun 2010) (Kusumadara, 2011).

Folklor adalah sebagian kebudayaan suatu kolektif yang tersebar dan diwariskan secara turuntemurun, diantara kolektif macam apa saja, secara tradisional dalam versi yang berbeda, baik lisan 
maupun contoh yang disertai dengan gerak isyarat atau alat pengingat (memonic device). Folklor dapat berupa bahasa rakyat, ungkapan tradisional (peribahasa), teka-teki, prosa rakyat (mitos, legenda dan dongeng), nyanyian rakyat, teater rakyat, permainan rakyat, arsitektur rakyat, musik rakyat dan sebagainya, (Danandjaja, 1984:2).

Sumenep merupakan salah satu kubupaten kecil di Madura yang jika ditinjau dari posisi geografisnya berada di ujung timur pulau Madura. Sumenep dalam hal kekayaan budaya nusantara merupakan salah satu wilayah dari empat kabupaten di pulau Madura yang ikut berperan aktif dalam merawat kekayaan khasanah budaya nusantara yang sangat beraneka ragam, di antaranya permainan rakyat dengan nyanyian-nyanyian. Ada beragam jenis permainan rakyat yang tumbuh di Indonesia dan Sumenep berada pada bagian terpenting yang memiliki kekayaan akan permainan tradisi itu.

Permainanan rakyat merupakan serangkaian kegiatan yang dilakukan oleh masyarakat pendukungnya sebagai upaya pembuktian eksistensi kedaerahan dan pembinaan dalam rangka pembentukan karakter, kesehatan jasmani dan sikap mental individu dan masyarakatnya. Nama lain dari permainan rakyat adalah permainan anak, karena umumnya permainan rakyat dimainkan oleh anakanak usia sekolah dasar.

Selanjutnya salah satu jenis keanekaragaman bentuk dan wujud permainan anak yang ada di Kabupaten Sumenep adalah permainan anak di Desa Saronggi Kecamatan Saronggi yang bernama permainan ti` titti liya 'liyu', cong-koncong konce, ra-ra kotana mera, ko-soko bucang, tong ta'etong dan jan-kolajang. Permainan tersebut dinilai cukup relevan jika ditinjau dari sisi bentuk folklor dan pelestarian nilai kearifan lokal permainan anak. Permainan anak seperti tan-pangantanan dan pesapean papa terdapat di Desa Kerta Barat Kecamatan Dasuk dan permainan ker-tanongker dan $p a^{\prime}$ 'opa' eling terdapat di Desa Juruan Daya Kecamatan Batuputih.

Fakta di lapangan menyatakan permainan anak di Kabupaten Sumenep saat ini mengalami kemunduran bahkan nyaris tersingkir dan ditinggalkan. Realitas tersebut berangkat dari fakta bahwa dahulu permainan anak dijadikan sarana pengisi waktu luang sebagai wujud interaksi sosial masyarakat. Saat ini permainan ini tidak lagi diterapkan dan diganti oleh permainan modern yang lebih menantang, se- perti halnya playstation, game online, game portable dan pokemon go yang bebas diakses anak-anak melalui gadgetnya masing-masing; kapan saja dan di mana saja. Nilai kerjasama, kekompakan dan keorganisasian yang terkandung dalam permainan anak saat ini terganti oleh individualitas yang tercipta lewat permaian modern. Begitu pula dengan kondisi sosial masyarakat sekitarnya dengan pola hubungan kekerabatan yang semakin jauh dari nilainilai karakter sebagai akibat lunturnya perhatian terhadap permainan anak di daerah-daerah tertentu.

Dalam rangka mengantisipasi serta menghindari hal tersebut, penting dilakukan penyelamatan melalui penelitian, dan pengkajian khusus baik dalam bentuk integrasi terhadap pembelajaran dan giat mendokumentasikan kebudayaan daerah yang ada. Terutama jenis folklor permainan anak yang kian menghawatirkan bahkan bisa dikatakan sudah lenyap, termasuk juga permainan anak di Kabupaten Sumenep. Tujuan penelitian ini adalah: (1) memperoleh deskriptif objektif mengenai bentuk folklor dan nilai kearifan lokal permainan tradisional yang dimainkan anak-anak; (2) mengidentifikasi permianan tradisional yang ada di Madura khususnya di Sumenep; dan (3) mengkaji permainan tradisional sebagai salah satu media dalam pembentukan karakter anak sekaligus sebagai stimulus perkembangan aspek fisik motorik, sosial emosional, kognitif dan bahasa.

\section{METODE}

Penelitian ini dilaksanakan di beberapa Desa di Kabupaten Sumenep yaitu di Desa Saronggi Kecamatan Saronggi, Desa Kerta Barat Kecamatan Dasuk dan Desa Juruan Daya Kecamatan Batuputih yang dikaji berdasar pada aspek-aspek yang mendukung di beberapa desa tersebut. Beberapa pertimbangan mengapa penelitian ini difokuskan di Desa Saronggi Kecamatan Saronggi, Desa Kerta Barat Kecamatan Dasuk dan Desa Juruan Daya Kecamatan Batuputih. Karena di sana masih terdapat permaian dengan iringan nyanyian tradisional, masih menjadikan permainan tradisional anak sebagai ajang permainan dalam waktu senggang, anak-anak di beberapa desa tersebut masih bisa melakukan permaian dan nyanyian anak secara tradisional dan adanya tokoh masyarakat yang cukup mengenal istilah nyanyian anak itu sebagai khazanah kebudayaan yang tertinggal dan nyaris dilupakan. 
Penelitian ini dilkasankan selama 5 bulan, terhitung mulai bulan Maret sampai dengan bulan Juli 2016. Sebagai upaya pemerolehan data maksimal, selama penelitian berlangsung peneliti melaksanakan kegiatan lapangan dengan cara berbaur dalam semua rangkaian permainan tradisional yang dimainkan oleh anak-anak setempat dari masing-masing desa di atas.

Penelitian ini termasuk pada jenis etnografi sebagai bagian dari penelititan kualitatif. Penelitian yang mengkaji budaya anak ini merupakan penelitian lapangan, sedangkan pendekatan yang dipakai adalah metode kualitatif dengan data berupa katakata tertulis atau lisan dari individu atau kelompok serta perilaku masyarakat pendukungnya.

Metode yang dimaksudkan dalam penelitian ini sejalan dengan pengembangan metode kualitatif yang digunakan Bodgan yaitu suatu cara yang digunakan untuk mendapatkan data deskriptif berupa tulisan, perkataan, ataupun tingkah laku. Metode penelitian kualitatif sering disebut metode penelitian naturalistik karena penelitiannya dilakukan pada kondisi yang alamiah (natural setting, disebut juga sebagai metode etnografi, karena pada awalnya penelitian ini lebih banyak digunakan untul penelitian bidang antropologi budaya. Disebut metode kualitatif karena data yang terkumpul lebih bersifat kualitatif (pertimbangan dari segi kualitas).

Optimalisasi dan keseriusan dalam kegiatan perekaman ini perlu dilaksanakan terhadap sastra lisan yang diteliti baik yang didongengkan, dinyanyikan atau di pertunjukkan. Dalam kegiatan pengumpulan data, ada beberapa teknik yang digunakan oleh peneliti di antaranya perekaman melaui handycame dan camera. Analisis data merupakan bagian yang tidak terpisahkan dari pengumpulan data, khususnya dalam penelitian folklor. Data dan informasi yang berhasil dikumpulkan secara berkelanjutan akan ditafsirkan.

Begitu juga dengan terkumpulnya data yang telah melewati berbagai proses diatas, mulai dari pengumpulan, transkripsi, dan penerjemahan hingga pada kegiatan akhir, yaitu analisis data. Dengan demikian, paneliti bisa melakukan langkah-langkah sebagai teknik analisa terhadap data yang diperoleh: (a) mengamati permaianan anak di Desa Saronggi Kecamatan Saronggi, Desa Kerta Barat Kecamatan Dasuk dan Desa Juruan Daya Kecamatan Batuputih; (b) mengkaji maksud makna kearifan lokan dan nilai-nilai karakter yang terdapat dalam permainan tersebut; (c) seleksi pada setiap kata atau kalimat dari transkripsi simbol-simbol dalam permainan tersebut dan menandainya sesuai dengan rumusan masalah yang ditetapkan; (d) identifikasi masalah serta singkronisasi dengan data yang diperoleh (e) penyimpulan data sesuai rumusan masalah.

\section{HASIL \\ Jelis Permainan Anak Tradisional di Sumenep Madura}

Pertama, Permainan Anak di Desa Saronggi Kecamatan Saronggi. Permainan anak merupakan permainan yang dimainkan oleh anak-anak dengan pengelompokan berdasarkan umur, dahulu permainan ini banyak dilakukan oleh anak-anak daerah pedesaan sebagai sarana hiburan dan kegiatan pengisi waktu luang. Jenis permainan anak sangat beranika ragam dan senantiasa berkembang dari masa ke masa, yang dipengaruhi oleh waktu yang digunakan. Hal ini terjadi pada setiap daerah termasuk di Desa Saronggi Kecamatan Saronggi.

Menurut data yang diperoleh dari informan di lapangan, ada sekitar enam jenis permainan anak yang berkembang dan sering dimainkan oleh informan dan kawan-kawan semasa kecil. Pada hakikatnya, ada banyak jenis permainan anak selain enam jenis tersebut, namun dikarenakan informan tidak bisa menjabarkan seluas mungkin yang disebabkan oleh faktor umur, maka informan hanya bersedia menjawab berdasarkan permainan yang diiangatnya saja. Dari hasil wawancara dengan informan, peneliti dapat menggolongkan enam jenis permainan anak yang terdapat di Desa Saronggi Kecamatan Saronggi, antara lain: a). Ti titi' liya liyu; b). Cong-koncong konce; c). Kotana meral; d). Ko-soko bucang; e). Tong-ta'etong; f). Jang-kolajang.

Permainan anak yang terdapat di Desa Saronggi Kecamatan Saronggi merupakan jenis permainan yang menggunakan nyanyian dan bahasa isyarat (gesture) atau bahasa tubuh sebagai pedoman gerakan dalam tata cara memainkannya. Nyanyian dan bahasa isyarat (gesture) atau bahasa tubuh tersebut dimaksudkan sebagai unsur daya tarik tersendiri dalam melakukan permainan tersebut Sebagaimana tujuan dasar permainan anak yaitu untuk menghibur.

Analisisnya, permainan anak di desa Saronggi Kecamatan Saronggi yang diiringi dengan nyanyian 
anak sebagai sebagai pengiring dan pedoman permainan mempunyai sifat mendidik atau dengan kata lain ada nilai karakter yang terkandung dalam permainan anak tersebut. Oleh karena itulah, penting kiranya ada kegaiatan pemeliharaan dan pelestarian permainan tersebut; baik sebagai kekayaan budaya atau sebagai sarana pengembangan karakter pada anak yang tidak lain adalah generasi masa depan bangsa. Permainan anak yang diiringi dengan nyanyian sebagai hiburan mempunyai sifatnya mendidik. Justru karena sifat mendidik itulah pertimbangan secara psikologis, pedagogis dan memperhatikan segala keperluan dan lingkup kehidupan yang khas itu, ranah ini menjadi sangat istimewa Sarumpaet (dalam Irmawati, 2007).

Lirik nyanyian anak yang dijadikan sebagai pengiring permaianan tersebut sebagai berikut.

\section{Ti'-Titi' Liya' Liyu \\ Ti'-titi' liya liyu \\ Poceddha koddhu' \\ $\mathrm{Na}$ - kana' cara reya \\ Esoddu'a malem senin \\ Dika pagar penang \\ Bula pagar bato \\ Dika ana'na temang \\ Bula ana'na rato \\ Dika toju' lantai \\ Bula toju'teker \\ Dika se apangantan \\ Bula se alengker}

Permainan Ti'-Titi’ Liya'Liyu

Permainan ini merupakan permainan anak yang dimainkan oleh dua sampai empat anak bahkan ada yang lebih. Jadi, permainan ini dapat dimainkan meskipun hanya dengan kuantitas 2 orang (anak) serta batas maksimal yang tidak terhingga atau dengan kata lain permainan ini bisa dilaksanakan secara beramai-ramai oleh banyak anak. Konsep pelaksanaannya, Permainan ini dilakukan dengan cara semua pemain (anak) duduk membentuk lingkaran. Kemudian seorang dari pemain meletakkan salah satu tangannya dengan posisi kelima jari dimekarkan (menapak kebawah hingga menyentuh lantai). Setelah itu salah satu dari anak tersebut ada yang menjadi pengarah permainan dengan cara menyanyikan lagu secara serentak dengan pemain lain. Kemudian aturannya, ketika lagu pengiring dimulai untuk dinyanyikan, salah seorang dari mereka menyentuh tiap jari yang dimekarkan di lantai tadi, seperti menghitung dengan penyesuaian hitungan jari dengan nyanyian.

Setelah nyanyian itu habis atau berhenti ditandai dengan sampai ditelunjuk mana nyanyian itu berakhir maka jari yang menempati nyanyian terakhir itu harus ditekuk. Begitu seterusnya sehingga jari siapa yang lebih banyak ditekuk maka dia yang kalah.

Pada umumnya, Permainan ini digunakan sebagai permainan untuk mencari siapa yang kalah (hanya satu orang) dalam permainan lain seperti petak umpet dan lainnya.

\section{Permainan Cong-koncong konce Cong-Koncong Konce}

\author{
Cong-koncong konce \\ Koncena lu'-ulu'an \\ Sabanyong sabiteng \\ Gik-enggik, rot-sorot \\ Pangantang tao abajang \\ Abajangnga keta'kedung \\ Ondurragi jung baba'an \\ "Nape so'on?" \\ "Tamanco"," \\ "hu, buwang, baji"” \\ "Nape pekol?" \\ "Geddhang" \\ "Geddhang nape?" \\ "Dhang canthel" \\ "Minta'a ce'-once'na bagiya \\ koceng edha'na tomang" \\ "ten, mi' egigiri mama", \\ "mama'na entar dhe' emma?' \\ "Entar muger perreng" \\ "Perrenga gabay nape?" \\ "gabay Cettheng" \\ "Cettheng kabaddha nape?" \\ "kabaddha nase"," \\ "nase'na pancal koceng, \\ kocengng buru ka pagar, \\ pagarra esolet caceng”
}

Permainan ini dimainkan oleh dua sampai empat anak bahkan ada yang lebih. Artinya, permainan ini dapat dimainkan oleh dua anak (batasan minimal) dengan batas maksimal yang tidak terhingga atau 
dengan kata lain permainan ini bisa dilaksanakan secara beramai-ramai oleh banyak anak. Dalam konsep Praktik di lapangan, Permainan ini dilakukan dengan cara para pemain duduk melingkar dan berhadap-hadapan, kemudian memposisikan tangan kiri mereka seperti menggenggam dengan pola tumpang tindih (tangan pemain satu dengan tangan pemain lainnya).

Setelah semua pemain memposisikan tangan mereka sampai keatas melalui pola tumpang tindih, pemilik tangan paling atas menggunakan telunjuk jari kanannya, dimasukkan pada lubang tangan paling atas kemudian digoyang-goyangkan sambil menyanyikan lagu tersebut. Setelah sampai pada lagu di bait terakhir " Ondurragi Jung Baba'an" semua bernyanyi lebih keras setengah berteriak dan posisi tangan paling bawah ditelungkupkan, begitu seterusnya.

Nyanyian dengan disertai gerakan tersebut dilakukan secara berulang-ulang hingga semua posisi tangan telungkup tumpang tindih satu sama lain. Setelah semua posisi tangan para pemain telungkup kemudian semua pemain meletakkan satu tangan bagian kanan ke atas kepala dan tangan kiri pada bagian bahu, kemudian dilanjutkan pada bait nyanyian yang dilafalkan dengan nada percakapan. Percakapan tersebut dimulai dari seorang yang bertugas menggoyang-goyangkan telunjuk jari pada permainan sebelumnya dengan susunan percakapan sebagai berikut.

“Nape so `on?” (orang pertama)

"Tamanco", (pemain lain serentak menjawab)

"hu, buwang, baji","

(pada kalimat ini, orang pertama yang mengucapkannya, gerakan tubuh dilakukan oleh semua pemain dengan cara mencium tangan kanan yang sebelumnya berada di atas kepala dengan gerakan membuang sesuatu) (selanjutnya kembali ke posisi semula, tangan kanan di atas kepala dan tangan kiri diletakkan dibahu, dan melanjutkan percakapan).

\footnotetext{
"Nape pekol?"

"Geddhang"

"Geddhang nape?"

"Dhang canthel"

"Minta'a ce'-once'na bagiya

koceng edha'na tomang"
}

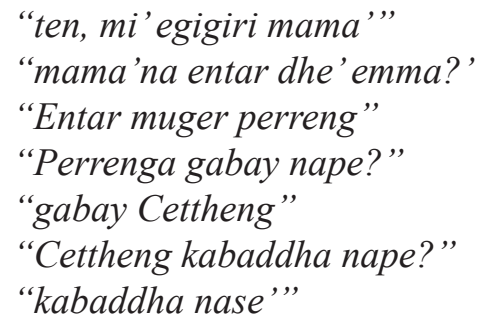

(pada bait terakhir ini, semua pemain mengucapkannya dengan serentak dan melafalkan kalimat dengan cepat sambil diiringi dengan tawa yang keras). "nase'na pancal koceng, kocengng buru ka pagar, pagarra esolet caceng”

\section{Permaianan Ra-ra kotana mera ra Ra-Ra Kotana Mera Ra}

\author{
Ra-ra kotana mera ra \\ Rambut tarkolanter tar kocebung-bung \\ Bungkel-kel buwana tar kolanter-ter \\ Tergu'gu'buwana ta'neng teggu'-gu' \\ Gumbing-bing sajikar-kar melli rambing-bing \\ Bintang gu'-teggu'na berras palotan-tan \\ Tandhu' manjamadin songkel sendho'-dho' \\ Dho'nang-nang kabunang nangka-ka \\ Kapor-por kaporra porron-ron \\ Rondhang-dhang katabing jeddhat
}

Lain halnya dengan Ti'- Titti' Liya' liyu' dan cong-koncong konce, Ra-ra kotana mera-ra sebenarnya tidak dikategorikan sebagai permainan. Ra-ra Kotana Mera ra hanya sebatas nyanyian yang dinyanyikan ketika waktu senggang. Nyanyian anak (rakyat) ini bisa dinyanyikan diberbagai tempat/ situasi seperti halnya setelah selesai ngaji, pada saat tiduran atau pada waktu bermain (berkumpul). Dalam praktek permainan ini, tidak ada gerakan khusus dalam nyanyian ini, hanya penekanan intonasi pada suara yang serentak.

Peraturan dalam permainan ini adalah barang siapa yang ketahuan tidak sama ketika bernyanyi (tidak serentak) maka dia diberi hukuman sesuai dengan kebijakan teman-teman lainnya. Meskipun demikian, bagi mereka (pelaku/pemain) hal ini termasuk permainan, karena jika dilihat dari lirik lagunya, ada banyak kata yang diulang dan ini dianggap lucu, sehingga nyanyian ini walaupun dimainkan tanpa gerakan tetap berlaku peraturan dan hukuman selayaknya permainan yang lain. 


\section{Permaian Ko-soko bucang Ko-Soko Bucang}

Ko-soko bucang

Bucangnga daja gunong

Ke temang mate

Mate esondep baringin

Baringinna konco'emmas

Saolor salaka

Nyaba' pondhuk ka taraktak

Taraktagga balang agung

Salang genta'titting

Kemma nyaba'kakan celeng

Permainan ini sejatinya sama dengan permainan sebelumnya, $t i{ }^{\prime}$ titti liya liyu'; baik dari jenis dan bentuknya, Hanya saja media permainan antara keduanya yang berbeda, media dalam permainan Ko-soko Bucang tidak menggunakan tangan melainkan menggunakan kaki. Tata cara permainannyapun sama, yaitu dengan menghitung antara kaki satu dengan yang lain.

Adapun konsep dalam permainan ini adalah dengan cara, para pemain sejajar duduk menyamping (tidak berhadapan) dengan posisi kaki diselonjorkan ke depan, setelah semua siap baru para pemain menyanyikan lagu sambil menghitung kaki-kaki yang diselonjorkan tadi. Kemudian ketika sampai pada bait terakhir, kaki yang mendapat giliran hitung bersamaan dengan habisnya bait nyanyian, maka dia harus menekuk salah satu kakinya, hingga yang terjadi, dia hanya mempunyai satu kaki yang diselonjorkan. Dan dia dinyatakan kalah dalam permainan. Permainan ini juga digunakan untuk mencari siapa yang kalah (satu orang) dalam permainan lain.

\section{Permaianan Tong-ta'etong Tong-Ta'etong}

Tong-ta'etong ta'etong tellorra kope' salaitong a'dhem pla'gupla'sidin bali'koko komel komella' meddem rek-komirek main dangga' danggarusan nyang-nyang maddu, kalambi sino'la'lorkong

\author{
ca'bulanceng nemmo pesse \\ saobang \\ kabelli jaran se dhabuk \\ etompa'nyai se oban gaggar \\ jalbuk \\ la 'can, sebuthak ngeco' acan \\ la'dem, se mella'meddem \\ paseret.
}

Tong Ta 'etong adalah nyanyian yang fungsinya tidak jauh beda dengan dua nyanyian di atas, $t{ }^{`}$ titti liya 'liyu` dan ko soko bucang yang digunakan dalam permainan peta' umpet. Hal ini menunjukkan adanya kekayaan budaya yang dilahirkan dari imaji dan daya kreatifitas masyarakat zaman dahulu (para sesepuh).

Permainan ini dilakukan dengan cara menghitung satu persatu para pemain. Kemudian nyanyian dilakukan secara serentak, secara otomatis nyanyian akan berhenti pada bait terakhir dan anak yang ditunjuk bersamaan dengan berakhirnya nyanyian adalah anak yang kalah. Selanjutnya para permain lainnya berlarian untuk mencari tempat persembunyian. Sedangkan yang kalah bertugas untuk mencari anak yang lain, yang sedang bersembunyi.

Dalm sistem dan prosedur permainan petak umpet, Permainan ini hanya digunakan diawal permainan, yang berfungsi sebagai penentu siapa pertamakali anak yang kalah dalam permainan ini dan menjadi subjek sentral dalam permaianan. Selanjutnya untuk menentukan yang kalah berikutnya adalah dengan cara ketika anak-anak lain bersembunyi dan ada yang ketahuan tempat persembunyiannya, maka anak yang pertama kali ketahuan itulah yang kalah dan dia bertugas seperti tugas yang kalah sebelumnya.

\section{Permainan Jang-kolajang Jang-Kolajang}

$$
\begin{aligned}
& \text { Jang-kolajang } \\
& \text { Kolajang ngekke' bunto' } \\
& \text { Jalto'rassa oto' } \\
& \text { Kalemmar matana tekko' } \\
& \text { Tekko'........ }
\end{aligned}
$$

Sama dengan tatacara permainan yang lain, Jang-Kolajang dimainkan oleh tiga anak atau lebih. Sederhananya, permainan ini adalah permainan 
strategi, yang mana merupakan permainan pertahanan benteng. Permainan ini dilakukan dengan cara membagi para pemain menjadi dua pihak. Anak pertama sebagai pihak musuh yang berhadapan dengan anak kedua yang mempunyai anak buah. jadi struktur permainannya adalah sebagai berikut:

Ada dua anak yang posisinya saling berhadapan, si A dan si B. Si A mempunyai anak buah yang ada dibelakangnya, sedangkan si B sendirian. Posisi dan tugas si A adalah mempertahankan anak buahnya yang diindikasikan dalam nyanyiannya itu dengan kata bunto 'atau ekor, jadi si A mempunyai anak buah dibelakangnya yang posisinya memanjang seperti ekor kebelakang, sedangkan si B mempunyai tugas merebut anak buah si A, maka ketentuan yang berlaku adalah jika si B berhasil menyentuh anak buah si A paling belakang, maka anak buah si A akan menjadi anak buah si B. Begitu seterusnya. Dalam konsep permainan ini, semakin banyak pemain yang menjadi ekor maka semakin mudah bagi pemain yang menjadi musuh untuk menarik pemain lain atau menarik ekor pemain inti.

Setelah si B berhasil merebut semua anak buah si A, secara otomatis posisi bergantian, si A bertugas mengambil anak buah si $\mathrm{B}$ dan si $\mathrm{B}$ bertugas mempertahankan anak buahnya dari serangan si A. Begitupun seterusnya secara bergantian.

Kedua, Permainan Anak di Desa Kerta Barat Kecamatan Dasuk. Dari hasil wawancara dengan informan, peneliti dapat menggolongkan dua jenis permainan anak yang terdapat di Desa Kerta Barat Kecamatan Dasuk, antara lain: a) Tan Pangantanan; b) Pesapean Pappa.

Permaianan anak tradisional Tan Pangantanan dan Pesapean Pappa adalah jenis permainan yang dalam permainannya juga diiringi nyanyian yang memiliki makna kearifan lokal dan sosial serta mengandung nilai karakter terhadap pembentukan kecakapan mental hidup seorang anak. Nyanyian anak yang dijadikan sebagai pengiring permaianan tersebut memakai lirik sebagai berikut;

\section{Dhe'Nong Dhe'Ne'Nang}

Dhe'nong dhe' ne' nang

Nanganang nganang nong dhe'

Nong dhe' ne' nang jaga jaggur

La sayomla haeto lillah

Ya amrasol kalimas topa'

Haena haedhang haena dhangkong
Pangantanna din ba'aju din tamenggung Ayola' yole nengkong abli pole ngantol

Koddu' pace pacenan, langsep buko lon alon

Pangantan ka'imma pangantan

Mantan loji pamaso'a ka karaton

Bu'saeng lema', bu'saeng lema'

Aeng tase' bang kambangan

Dhu panarema, dhu panarema

Balanjana saare korang

Bidaddari le' bidaddar kong

Nase'obi le' kowa lurking

Ban-gibannna le' nase' jagung

Pangerengga le' pate' buttong

$Y a$, hadirin tore so'onnagi

Paneka pangantan sopaja kengeng salamet

Ya salam, ya salam

Kitab suci dah lama-lamanya

Kini pengantin lah tiba lah tiba

Kepada kawan-kawanku semua

Mudah-mudahan berjumpa lagi

Tan-taretan sadajana e dalem somana

Di sana e ka'dinto Karangduwek nyamaepon

Nyara taretan abadi kacintaan abadi

kanesseran

Olle tetep Islam ban Iman

Jam yuju jam delapan, ana'serdadu mekol senapan (dar)

Yam berana' etekla ayam pengantin baru

sudah berjalan

Tette ajam bindhara, pangantan ka' imma

pangantan

Pangantanna din ba'aju din tamongkong

Jas Turki pakaian celana puti

Aan'ayam berani mati, jas turki sudah mati

La bu'na mela, ajam pote

Cocco'sengkang e soro pajikaran

Permainan ini, dahulu menjadi tradisi, saat ini sudah sangat jarang yang bermain tan-pangantanan. Permainan tradisi ini dipraktikkan oleh anak-anak di waktu santai. Waktu bermain tradisi ini setelah panen raya, biasanya ketika anak-anak selesai membantu panen di sawah. Mereka sepakat berhimpun, kemudian secara spontan membentuk kelompok yang terdiri dari kelompok utama (perempuan) dan kelompok besan (laki-laki). Kedua kelompok tersebut kemudian berlomba memberi hiasan serupa penganten kepada masing-masing jagoannya. Kondisi saat ini sudah lain, tan-pangantanan secara natural sudah tidak ada lagi, beralih penganten yang serius 
ketika ada acara haflatul imtihan dan karnaval dengan biaya yang tinggi.

Sementara Pesapean Pappa adalah sapi mainan anak kecil di Madura berupa sapi-sapian yang terbuat dari pelepah pisang. Sejak kecil, anak-anak kecil di Madura telah akrab dengan mainan sapi tersebut. Dalam permainan ini seringkali diiringi nyanyian sebagai penanda sorak sorai dan kegembiraan khas anak-anak. Saat ini, mainan serupa sapi ini sudah dilupakan oleh anak-anak kecil.

\section{Gai’ Bintang}

Gai'bintang a le'gaggar bulan

pagai'na janor konéng

kaka'elang a le' sajan jau

pajauna e lon-alon

liya lites, kembang ates, tocca'toccer

Masyarakat Madura meyakini dengan mainan Pesapen Pappa, bocah-bocah itu bisa mencari impiannya sendiri. Ia bebas berimajinasi kemana saja. Terbang sesuai keinginannya dengan berkendara sapi mainan itu. Mainan bagi anak-anak kecil sebagai sarana bermain dan berimajinasi harus tetap dilestarikan karena itu bagian dari pelestarian nilai kearifan lokal.

Ketiga, Permainan Anak Di Desa Juruan Daya Kecamatan Batuputih. Sebagaimana di dua desa yang lain, menurut informan permaian anak tradisional yang terdapat di desa Juruan Daya Kecamatan Batuputih adalah permainan yang diiringi nyanyian-nyanyian. Jenis permainan di desa ini adalah a). Ker-Tanoker; b). Pa'Opa'Eling/ Pa'Kopa'Eling.

Ker-Tanoker dan $\mathrm{Pa}^{\prime}$ Kopa' Eling ada yang menyebut $\mathrm{Pa}^{\prime} \mathrm{Opa}^{\prime}$ Eling juga, merupakan permainan yang memiliki lirik nyanyian yang arti dan maknanya kaya akan pembentukan sikap, etika untuk menjadikan pribadi anak yang berkarakter dan mempunyai empati luar biasa serta mudah memaafkan apabila betul-betul salah . Nyanyian anak yang dijadikan sebagai pengiring permaianan tersebut liriknya sebagai berikut;

\section{Ker-tanongker}

Ker-tanongker, dimma bara' dimma temor Ker-tanongker, sapa se soker, nyapa $k a$ 'ada'lanjang omor

\section{Dalam versi lain}

\section{Ker-tanongker}

Ker-tanongker, dimma bara'dimma temor

Ker-soker, sapa nyapa kaadha' lanjang omor

Ker-tanongker jambuna massa' saseba'

Ker-tanongker $r$ lagguna nyapa kaadha'

Ker-tanongker jambuna massa' sapennay

Ker-tanongker lagguna nyapa e songay

Ker-tanongker jambuna massa' sacorong

Ker-tanongker lagguna nyapa e lorong

Ker-tanongker jambuna massa' pagar

Ker-tanongker lagguna nyapa e langgar

Tanongker adalah kepompong. Anak-anak madura lebih mengenal tanongker daripada kepompong. Lirik di atas sebagai pengiring anakanak bermain. Tanongker merupakan makhluk hidup jelmaan ulat yang sedang bermetamorfosis untuk menjadi kupu-kupu yang cantik dan indah. Permainan Ker-Tanongker ini identik dengan perselisihan dan salah paham. Sebagai media memperbaiki persahabatan, anak yang berselisih paham biasanya memanfaatkan permaianan ini untuk rujuk atas keretakan persahabatannya. Dalam bahasa madura atokar sehingga berdampak soker adalah dua hal permasalahan seringkali terjadi di lumbung permainan anak-anak di madura.

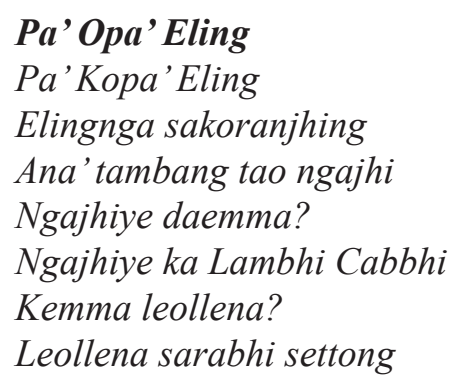

$\mathrm{Pa}^{\prime} \mathrm{Opa}$ ' eling adalah tradisi permainan anakanak di Sumenep Madura, yang pada jamannya cukup diminati. Ketika tera'bulan (purnama) adalah 
waktu yang tepat dan digandrungi, karena pada saat purnama tersebut anak-anak bisa bersuka cita dan meluapkan kegembiraannya. Anak-anak berkumpul di halaman rumah dan berkelompok. Biasanya yang paling disukai oleh anak-anak adalah menyanyikan lagu $\mathrm{Pa}^{\prime}$ Opa' Eling, secara bergantian mereka menyanyikan lagu ini dan disertai pula dengan tepuk tangan.

\section{PEMBAHASAN}

\section{Pembentukan Karakter Anak melalui Permainan Anak Tradisional}

Sejak tahun 2011, pemerintah melalui Mendiknas merumuskan nilai-nilai karakter yang harus disisipkan kepada setiap proses pendidikan peserta didik dari semua jenjang dan tingkatan yang ada di Indonesia terutama sejak usia Sekolah Dasar. Penelitian ini mengambil peran bagaimana permainan anak tradisional yang mulai ditinggalkan anak-anak dan masyarakat harus kembali diupayakan dan dibangkitkan karena memiliki kaitan erat dengan pembentukan karakter anak sebagaimana rumusan nilai-nilai karakter oleh pemerintah.

Pertama, Nilai Spiritualitas. Permainan anak tradisional dengan nyanyian anak di Desa Saronggi Kecamatan Saronggi, folklor dalam bentuk permainan rakyat ini juga memiliki nilai-nilai, salah satunya adalah nilai spiritual. Seperti yang ditunjukkan dalam permainan ko-soko bucang berikut.

\author{
Ko-soko bucang \\ Bucangnga daja gunong \\ Ke temang mate \\ Mate esondep baringin \\ Baringinna konco'emmas \\ Saolor salaka \\ Nyaba' pondhuk ka taraktak \\ Taraktagga balang agung \\ Salang genta'titting \\ Kemma nyaba'kakan celeng \\ Terjemahan bebas: \\ Kaki-kaki betis \\ Betisnya orang utara gunung \\ Ki Temang mati \\ Mati terantuk pohon beringin \\ Beringin berkuncup emas \\ Sebatang perunggu
}

\author{
Menaruh pondok ke suatu tempat \\ Tempat tinggi yang diagungkan \\ Saling menghentakkan kaki sambil berjinjit \\ Seperti menaruh (sesuatu yang) dimakan \\ babi hutan
}

Kematian adalah keharusan, semua manusia harus mempersiapkan untuk menjadi kehidupan berikutnya di alam kubur, semua manusia berharap bisa hidup tenang dan damai pada kehidupan berikutnya tanpa siksaan sebagai pertangung jawaban ketika menjalani kehidupan sebelumnya.

\section{Ko-soko bucang \\ Bucangnga daja gunong \\ (Kaki-kaki betis \\ Betisnya orang utara gunung)}

Kalimat kaki-kaki betis secara implisit bisa dijelaskan dengan parafrase kalimat, yaitu kakikaki (nya) betis. Kalimat "nya" memiliki makna kepunyaan, sedangkan kata ulang pada kata "kaki" mempunyai makna lebih dari satu. Hal ini dimaksudkan sebagai penjelasan bahwa dua kaki yang digunakan sebagai penyanggah dari betis sebagai struktur otot dalam organ tubuh manusia.

Filosofis kalimat tersebut merujuk pada kebiasaan orang madura yang dikenal dengan masyarakat perantau. Dalam tradisi masyarakat Madura, merantau adalah sebuah kondisi sosial yang seperti menjadi ukuran "wajib". Ini biasanya berlaku bagi mereka-mereka yang masih muda. Etos kerja semacam ini sudah banyak dikenal di berbagai belahan masyarakat manapun, bahwa masyarakat Madura memang terkenal dengan masyarakat perantau. Merantau berarti mencari sesuatu yang lain, bukan berarti tidak puas dengan apa yang telah didapat tetapi demi mencari pengalaman dalam rangka memperkaya pengetahuan dan menciptakan sebuah suasana baru demi mengejar kemamkmuran dan kejayaannya, masyarakat madura sudah menjadikan hal semacam ini seperti keharusan.

\author{
Ke temang mate \\ Mate esondep baringin \\ (Baringinna konco'emmas Saolor salaka) \\ (Ki Temang mati \\ Mati terantuk pohon beringin \\ Beringin berkuncup emas Sebatang perunggu)
}


Pada bait Ke Temang mati, Mati terantuk pohon beringin, Beringin (yang) berkuncup emas (dan) Sebatang perunggu ini, menyatakan bahwa kematian yang diinginkan manusia adalah khusnul khotimah,. Panggilan Ke berarti Kyai, orang paling dihormati dalam strata sosial masyarakat agamis. Sedangkan pada bait mati teraktuk beringin, dan beringin itu berkuncup emas dan sebatang perunggu ada kata terantuk. Terantuk bukan berarti terbentur atau penyebab kematian tapi lebih kepada tafsir bahwa kematiannya itu bersandar pada pohon beringin yang berkuncup emas dan sebatang perunggu. Sedangkan kuncup emas dan sebatang perunggu pada pohon beringin adalah sebuah wacana penghargaan atas amal yang dikerjakan semasa hidup, sehingga kelakuan dan perbuatannnya selama hidupnya berbuah emas dan perunggu yang di tempatkan di tempat tinggti yaitu pucuk pohon beringin.

\section{Nyaba' pondhuk ka taraktak \\ Taraktagga balang agung \\ Salang genta'titting \\ Kemma nyaba'kakan celeng \\ (Menaruh pondok ke suatu tempat \\ Tempat tinggi yang diagungkan \\ Saling menghentakkan kaki sambil berjinjit \\ (awas) Di mana tempat itu ditaruh, \\ dimakan babi hutan)}

Dalam bait terakhir nyanyain tersebut juga menyebutkan adanya "buah manis" dari segala usaha yang dicoba. Usaha yang dilakukan dengan sungguh-sungguh diibaratkan seperti menempatkan sesuatu di tempat yang tinggi. Disini, sesuatu tersebut dianalogikan dengan "pondok" atau pondhuk dalam bahasa Madura. Pondhuk bermakna tempat tinggal (menyerupai warung) yang biasanya digunakan sebagai tempat ngaso di sawah atau ladang, pos kamling desa bahkan ada yang dijadikan tempat tinggal, pondhuk terbuat dari kayu dan bambu yang dibuat menyerupai rumah.

Pondhuk menjadi pilihan untuk diibaratkan sebagai sesuatu yang berharga, yang perlu diarak ke suatu tempat yang tinggi. Pondhuk menjadi sangat bernilai karena dilihat dari segi fisiknya yang digunakan sebagai tempat yang bisa memberikan efek nyaman bagi penggunanya. Tempat yang tinggi tersebut adalah tempat yang diagungkan, sambil saling menghentakkan kaki dan berjinjit tanda kegirangan. Hal ini menunjukkan bahwa buah dari perjalanan itu perlu dijaga ketat dengan tujuan tidak "dimakan babi". Kalimat penjelas "dimakan babi" bisa bermakna "suul khotimah".

Kedua, Nilai Karakter Disiplin dan Menghargai. Salah satu nilai yang terdapat dalam folklor permainan anak tradisional adalah nilai pendidikan karakter. Pendidikan karakter sangat penting demi menopang generasi yang berpijak pada kebajikan para pendahulu bangsa ini.

Penyajian tentang kebijakan dalam pola mendidik anak sebagai jalan menuju pendidikan dapat dijumpai pada semua pola permaianan anak dalam penelitian ini. Pada umumnya, setiap permainan mempunyai ketentuan-ketentuan yang tidak boleh dilanggar dan ketentuan-ketentuan yang diwajibkan selama permainan. Kebijakan tersebut dapat saja diubah sesuai dengan kesepakatan bersama. Salah satu contoh adalah permainan jangkolajang. Dalam permaianan ini ada tatacara dan kebijakan dari kedua belah pihak. Salah satu bentuk kebijakan itu adalah pada kasus permainan antara si A melawan si B, ketika si B berhasil menyentuh anak buah si A, maka anak buah si A wajib menjadi anak buah si $\mathrm{B}$ dan harus berpindah tempat kebelakang si B.

Pola pendidikan karakter semacam ini adalah ajaran tentang kebijakan yang diadaptasi dalam bentuk permainan anak tradisional supaya anak mennyadari bahwa pentingnya menjalin kerjasama dengan berpijak pada aturan yang harus dipahami dan tidak untuk dilanggar. Kondisi ini dikuatkan hasil penelitian (Badeni \& Agus, 2014) antara lain terdapat dua basis kearifan lokal yang diterapkan oeh guru tingkat SD/MI dalam melaksanakan pendidikan nilai budi pekerti/karakter yaitu (a) kearifan lokal berbasis agama dan, (b) kearifan lokal berbasis ungkapan yang hidup dalam kehidupan masyarakat.

Ketiga, Nilai Etika dan Moral. Nilai etika dan moral adalah sebuah keharusan yang harus ditanamkan sejak kecil kapada anak. Moral dapat diartikan sebagai tindakan yang pisitif, atau tindakan yang menimbulkan efek samping berguna. Ajaran-ajaran moral berlaku dalam bidang, dakwah agama dan pengajian, protes sosial, pendidikan dan lain-lai.

Nilai etika dan moralitas yang tinggi harus dijunjung tinggi sehingga tidak gampang disalahgunakan dan mampu diamalkan karena ilmu pengeta- 
huan berada di dua dimensi, antara kebaikan dan kejahatan. Ilmu pengetahuan akan mendatangkan bencana apabila dipergunakan oleh orang-orangnya tidak beretika dan moralnya sangat rendah serta tidak bertanggung jawab, sebaliknya ilmu pengetahuan akan membawa manfaat serta kemaslahatan bagi umat manusia apabila berada di tangan-tangan manusia yang bertanggung jawab dari sisi moralitas dan etika. Hal tersebut dapat disimak pada bait berikut;"e cocco' dhangdhang pote keba mole, $e$ cocco' dhangdhang celleng keba melleng" (dipatuk elang putih di bawa pulang, dipatuk elang hitam di bawa nakal). Sesuai dengan nilai etika dalam permainan anak dinyatakan pada hasil penelitian (Suryanto. 2014) bahwa keefektifan model pendidikan budi pekerti dapat digunakan untuk meningkatkan kemampuan penanaman nilai-nilai etis-spiritual secara efektif di SD.

Dalam folklor, nilai moral juga diperhitungkan, kalimat satire berupa sindiran kritis tentang moral, akhlak, sopan satun masyarakat dapat dilihat dari bagian kedua bait cong-koncong konce. Moralitas adalah hal yang sangat penting, perlu dijaga oleh seluruh masyarakat pada supaya tidak bersinggungan antara kepentingan satu dengan kepentingan yang lain. Hal tersebut ditunjukkan dalam bait cong-koncong konce berikut.

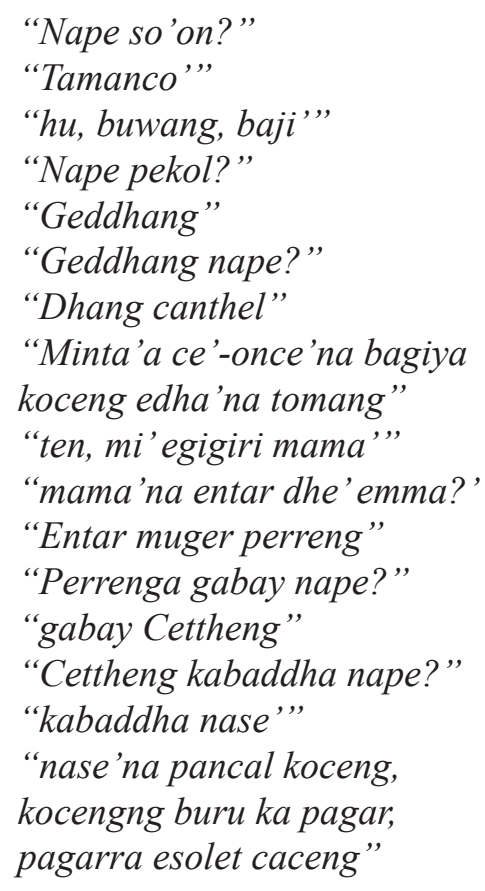

\section{Terjemahan bebas:}

"apa yang disunggih?"

"tai (kotoran) ayam"

"hu, buang, jijik"

"apa yang dipikul?"

"pisang"

"pisang apa?"

"pisang canthel (jenis buah pisang)"

"mau minta ce' once'na (yang sudah tidak

diperlukan) mau dikasi kucing depan tungku"

"tidak, takut dimarahi bapak"

"bapaknya ke mana?'

"pergi menebang bambu"

"bambu mau dibuat apa?"

"dibuat Cettheng (anyaman bambu yang

dibuat tempat basuh beras atau makanan,

bentuknya seperti ember kecil)"

"Cettheng mau dibuat wadah apa?"

"sebagai tempat nasi"

Kondisi moral sudah ditunjukkan dalam percakapan tersebut. Meskipun terjadi dalam permainan, namun sarat nilai dan maknanya masih kental. Bisa diartikan bahwa kita tidak boleh menjawab sembarang pertanyaan orang lain, atau kita harus menjaga sikap kita dalam perbicara meskipun lawan bicara kita itu ngeyel. Sudah tahu tidak dikasi malah masih bertanya. Konsep moral yang ada dalam permainan anak cong-koncong konce ini mengajarkan bagaimana menjaga sikap dan hati ketika berhadapan dengan orang lain.

Keempat, Nilai Peduli Sosial.

Permainan $t i{ }^{\prime}$ tiiti` liya 'liyu` juga mendapat bagian untuk diadaptasi kedalam bentuk hubungan antar masyarakat. Salah satunya dalam permainan ini ada lagu pengiring yang bercerita tentang strata sosial dalam masyarakat, saling hormat dan saling pandang dan rendah hati.

Dika pagar penang

Bula pagar bato

Dika ana'na temang

Bula ana'na rato

Dika toju' lantai

Bula toju`teker 
Terjemahan bebas:

Kamu pagar pinang

Saya pagar batu

Kamu anaknya temang

Saya anaknya raja

Kamu duduk dilantai

Saya duduk di karpet

Selanjutnya Pesapen pappa merupakan mainan anak kecil berupa sapi-sapian yang dibuat dari pelepah pisang. Saat ini, mainan serupa sapi ini sudah dilupakan oleh anak-anak kecil. Mereka lebih memilih mainan buatan pabrik. Di samping bermakna sebagai mainan anak kecil, Pesapen Pappa seringkali dijadikan sebagai ungkapan sindiran terhadap orang yang tidak memiliki prinsip hidup dan tidak memiliki ketegasan dalam berkomitmen. Semisal ungkapan jak daddi pesapean pappa, eajak kabara'noro 'kabara' eajak ka temor noro' ka temur (jangan jadi pesapean pappa atau ikut-ikutan, diajak ke barat ikut ke barat, diajak ke timur ikut ke timur). Sindiran semcam ini efektif secara sosial untuk memberikan ruang kesadaran terhadap genarasi muda yang tidak memiliki prinsip hidup dan prinsip budaya.

Kelima, Nilai Cinta Damai, Toleransi dan Bersahabat. Hanya orang-orang matang secara mental yang mampu mengalah dan memafkan. Sikap mengalah dan sifat pemaaf adalah sebuah nilai yang harus dimiliki oleh setiap anak dan sudah ditanamkan sejak usia anak-anak. Syair Ker-tanoker mengajari anak-anak bagaimana seharusnya menghadapi pertentangan maupun pertikaian, salah satunya memberikan ruang mengalah. Ruang-ruang diplomasi dapat dilakukan oleh anak-anak dimana saja, terutama di tempat-tempat bermain dan berkumpul. Tempat-tempat tersebut, antara lain di sungai ketika mandi, di jalan, di surau, maupun di pasar. Berikut adalah syairnya:

Ker-tanoker lagguna nyapa kaadha'/Kertanoker lagguna nyapa e songay/Ker-tanoker lagguna nyapa e lorong/Ker-tanoker lagguna nyapa e langgar. (Bila tak bertegur sapa, besok menyapa duluan/Boleh bertengkar besok menyapa di sendang/Boleh bertengkar besok menyapa di jalan/ Boleh bertengkar besok menyapa di langgar). Diksi syair Ker-tanoker sangat sederhana tetapi mempunyai makna luar biasa dalam hal kematangan pribadi setiap anak, yaitu bagaimana setiap pribadi mampu menunjukkan kematangannya baik secara psikis mampun fisik. Hanya dengan kematangan secara pribadi, segala bentuk perbedaan dapat diselesaikan. Niscaya pintu kerukunan dan perdamaian akan terbuka lebar.

Nilai etika dan moralitas tinggi semacam ini yang harus dijadikan perenungan untuk membangun generasi muda dalam bertarung menghadapi terpaan dan ujian globalisasi. Pembentukan karakter anak usia SD melalui aktivitas apresiatif dan kreatif berbasis tradisi nyanyian kelokalan memberikan dampak yang positif bagi tumbuh kembang mentalitas estetik. Dinyatakan hasil penelitian (Hidayat. 2013) bahwa Wayang Topeng Malang (WTM) merupakan transmisi nilai-nilai lokal yang mengikat hubungan sosial antar individu dalam bermasyarakat, berdasarkan berbagai potensi berkesenian dalam dina-mika masyarakat di Malang. Juga ditegaskan bahwa nilai-nilai kultural berdampak pada kearifan lokal tentang pendewasaan mentalitas estetik pertumbuhan siswa sekolah (utamanya siswa SD kelas rendah. Adanya manfaat positif pembentukan karakter melalui nyanyian tradisional anak usia SD juga dinyatakan pada hasil penelitian (Akbar. 2014) bahwa penyelenggaraan pendidikan karakter yang baik dapat mengembangkan prestasi yang tinggi bagi peserta didik.

\section{SIMPULAN DAN SARAN}

\section{Simpulan}

Kearifan lokal berbasis permainan tradisional sangat penting terhadap pembentukan karakter anak Indonesia khususnya di Sumenep Madura karena permainan anak tradisional yang ada di Sumenep memiliki makna dan kaya akan nilai-nilai karakter pembangun jiwa, sikap dan mental usia anak-anak. Nilai-nilai tersebut di antaranya; (a) nilai spritual, (b) nilai karakter disiplin dan menghargai, (c) nilai etika dan moral, (d) nilai peduli sosial, (e) nilai cinta damai, toleransi dan bersahabat. Selain dari nilai-nilai tersebut permainan anak tradisional ini merupakan saran hiburan yang dapat menjalin keakraban dan persaudaraan sesama teman.

\section{Saran}

Para peneliti hendaknya terus melakukan penelitian lanjutan untuk mencari dan memahami nilai-nilai yang terkandung dalam permainan (nyanyian) anak tradisional untuk pembentukan karakter anak terutama dalam khazanah sastra lisan 
(folklor) dan kebudayaan Nusantara khusunya di Madura. Perlunya dukungan masyarakat terhadap pelestarian kebudayaan lokal yang mengandung banyak nilai kearifan dan nilai edukatif dalam menanamkan sikap berkarakter terhadap anak, karena darinya kita bisa lebih mencintai dan menunaikan tugas untuk merawat kebudayaan warisan leluhur untuk lebih memahami hidup dan kehidupan dalam kaitannya dengan dimensi kemanusiaan yang arif dan bijaksana.

\section{DAFTAR RUJUKAN}

Akbar, S. 2014. Model Pendidikan Karakter yang Baik (Studi Lintas Situs Bests Practices) Pendidikan Karakter di SD. Jurnal Sekolah Dasar. 23(2):139-151.

Badeni, Saparahayuningsih, S., \& Makmurtono, A. 2014. Model Pendidikan Nilai Budi Pekerti Berbasis Kearifan Lokal bagi Siswa SD. Jurnal Sekolah Dasar. 23(1):19-30.
Danandjaja, J. 2002. Folklor Indonesia, Jakarta: Pustaka Utama Graffiti Moleong.

Hidayat, R. 2013. Tranformasi Nilai Lokal Wayang Topeng Malang sebagai sumber Pendidikan Karakter Siswa SD. Jurnal Sekolah Dasar. Th. 22 No. 2 November 2013:83-90. Malang: Prodi PGSD FIP UM.

Irmawati, L. R.2007.Serial Kidung Anak: GAI BINTANG. Sumenep: Dinas Pariwisata dan Kebudayaan Kabupaten Sumenep

Kusumadara, A. 2011. Pemeliharaan dan Pelestarian Pengetahuan Tradisional dan Ekspresi Budaya Tradisional Indonesia: Perlindungan Hak Kekayaan Intlektual dan Non-Hak Kekayaan Intlektual Jurnal Hukum. Vol. 18 Januari 2011. Suryanto, E. 2014. Keefektifan Model Pendidikan Budi Pekerti Berbasis Cerita Anak Melalui Penanaman Nilai Etis-Spiritual Siswa SD. Jurnal Sekolah Dasar. 23(1):41-51. 